\title{
As Consequências das Violações aos Direitos Fundamentais Durante a Ditadura Militar
}

\section{Lucas Goulart da Silva}

Advogado. Graduado em Direito pela Universidade Regional do Noroeste do Estado do Rio Grande do Sul (Unijuí) (2002). Pós-graduado em Processo Civil pela Unijuí (2007). Mestre em Desenvolvimento pela Unijuí (2012). Professor da Faculdade América Latina. Iucasijui@yahoo.com.br

\section{Resumo}

0 presente artigo tem como objetivo abordar os reflexos atuais oriundos das violações aos direitos fundamentais durante a ditadura militar, estabelecendo-se um paralelo com a tentativa brasileira de revisão da Lei de Anistia por meio da Arguição de Descumprimento de Preceito Fundamental ํo 153, ação judicial proposta pelo Conselho Nacional da $O A B$ e negada pelo Supremo Tribunal Federal, que reafirmou a validade da lei. Será analisada a condenação sofrida pelo Brasil no caso Gomes Lund vs. Brasil, perante a Corte Interamericana de Direitos Humanos, na qual o Estado brasileiro restou obrigado a reparar os danos causados às vítimas pelas atrocidades cometidas durante a Guerrilha do Araguaia.

Palavras-chave: Direitos e Garantias Fundamentais. Violação de Direitos. Ditadura Militar.

\section{THE CONSEQUENCES OF FUNDAMENTAL RIGHTS VIOLATIONS DURING MILITARY DICTATORSHIP}

\begin{abstract}
This article aims to address current reflections from violations of fundamental rights during the military dictatorship, establishing a parallel between the Brazilian attempt to revise the Amnesty Law, which happened through the complaint of breach of Fundamental Precept n. 153, a legal action filed by the National Council of Lawyers $(O A B)$ and denied by the Supreme Court, which reaffirmed the validity of the law. Consideration will be given for costs incurred in the case of Brazil vs Gomes Lund. Brazil, examined by the Inter-American Court of Human Rights, in which the Brazilian government remains obligated to repair damages caused to the victims for atrocities committed during the Araguaia guerrilla movement.
\end{abstract}

Keywords: Fundamental Rights and Guarantees. Violation of Rights. Military Dictatorship.

\section{Sumário}

1 Introdução. 2 As consequências das violações aos Direitos fundamentais durante a ditadura militar. 3 A Abertura política e a Lei de Anistia (Lei no 6.683/79). 4 A Comissão da Verdade e a Lei de Acesso à Informação 5. Conclusão. 6 Referências 


\section{INTRODUÇÃO}

A controvérsia causada pela interpretação ampla da Lei de Anistia motivou o ajuizamento da ação de Arguição de Descumprimento de Preceito Fundamental (ADPF) pelo Conselho Federal da Ordem dos Advogados do Brasil (OAB). O Supremo Tribunal Federal, em 29 de abril de 2010, no entanto, decidiu pela improcedência da demanda, que possibilitaria a investigação por abusos cometidos durante os “anos de chumbo", responsabilizando os envolvidos pelos crimes cometidos. Trata-se de possibilidade que gera revolta no meio militar brasileiro, que se julga amparado pelo direito anteriormente adquirido.

A decisão expôs o Estado brasileiro ao julgamento perante a Corte Interamericana de Direitos Humanos (CIDH), órgão criado no âmbito da Convenção Americana de Direitos Humanos, que, em 24 de novembro de 2010, condenou o Brasil pelas atrocidades cometidas durante a Guerrilha do Araguaia (Caso Gomes Lund e Outros vs. Brasil). Entenderam os juízes da Corte que o Brasil descumpriu a obrigação de adequar seu direito interno à Convenção, incluindo neste item a controversa Lei de Anistia. De forma conclusiva, entenderam os julgadores que as medidas adotadas pelo Brasil, como a Lei de Anistia e a política de indenizações e benefícios, não se constituíram em uma "reparação suficiente" às violações de direitos alegadas pelas vítimas e seus familiares.

A condenação sofrida não possui recurso, e inclui a criação da Comissão da Verdade e da Lei de Acesso à Informação, institutos recentemente adotados e que possuem efeitos ainda desconhecidos da sociedade. $\mathrm{O}$ presente artigo analisa os recentes fatos oriundos da ditadura militar, seus reflexos e possíveis consequências. 


\section{AS CONSEQUÊNCIAS DAS VIOLAÇÕES AOS DIREITOS FUNDAMENTAIS DURANTE A DITADURA MILITAR}

Os reflexos das violações aos direitos fundamentais iniciaram-se tão logo estas passaram a ocorrer. O Brasil anterior ao golpe militar estava sob a égide da democrática Constituição Federal de 1946, influência sofrida pelo processo de redemocratização posterior à queda de Getúlio Vargas. Vigorou por 18 anos, sendo interrompida bruscamente por um período de 21 anos de constantes violações de direitos, transformando a História do país e de gerações de brasileiros.

Com o fim da ditadura e a promulgação da Constituição Federal de 1988, intensificaram-se as tentativas de responsabilização civil e criminal dos agentes militares. Seguindo os moldes sul-americanos, as vítimas e seus familiares passaram a pressionar por medidas que reparassem as violações ocorridas.

Em setembro de 2006, foi aceita no Brasil uma ação inédita de responsabilização de um torturador do período ditatorial. O juiz Gustavo Santini Teodoro, da $23^{\text {a }}$ Vara Cível de São Paulo, acolheu Ação Declaratória impetrada em 2005 pela família Almeida Teles contra Carlos Alberto Brilhante Ustra - comandante do DOI-CODI/SP entre $1970 \mathrm{e}$ 1974 - por entender que a ofensa aos direitos humanos não está sujeita à prescrição (DOSSIÊ DITADURA, 2009, p. 46).

Somente em 2010, entretanto, medidas mais contundentes foram tomadas no sentido de punir efetivamente os autores dessas violações, com destaque para a tentativa de revisão da Lei de Anistia (Lei ${ }^{0}$ 6.683/79), promovida por meio da Arguição de Descumprimento de Preceito Fundamental no 153 (ADPF), ação ajuizada pelo Conselho Federal da Ordem dos Advogados do Brasil perante o Supremo Tribunal Federal, e o julgamento do caso Gomes Lund (Caso $\mathrm{n}^{\circ}$ 11.552) sobre crimes ocorridos durante a Guerrilha do Araguaia entre os anos de 1972 e 1975, perante a 
Corte Interamericana de Direitos Humanos. Esses processos inauguraram um novo período de reparação aos direitos humanos violados no Brasil, contribuindo para a consolidação da democracia e a reparação dos danos sofridos.

Apesar da improcedência da ação de Arguição de Descumprimento de Preceito Fundamental julgada pelo plenário do STF em 29 de abril de 2010, a negativa da possibilidade de revisão da controvertida Lei de Anistia brasileira, que, segundo Fábio Konder Comparato, procurador que representou a Ordem dos Advogados do Brasil no julgamento da demanda, tinha por objetivo "recuperar a honorabilidade das Forças Armadas, após os atos de arbitrariedade - terrorismo, sequestro, assalto, tortura e atentado pessoal - praticados por integrantes da corporação contra opositores do regime militar" (ADPF/153, 2010), externou o desejo da sociedade em retroagir ao passado, sepultando os resquícios das violações anteriormente praticadas.

A demanda tinha por escopo punir tão somente os agentes públicos que, sob a égide do Estado, cometeram crimes contra o cidadão. Segundo Comparato (2005), "se a lei tivesse anistiado os agentes públicos que cometeram milhares de atos de tortura durante o regime militar, esta anistia teria sido recepcionada no texto da Constituição Federal de 5 de outubro de 1988. Mas isto não ocorreu” (ADPF/153, 2010).

Nesse sentido, é importante destacar o exposto pelo Ministro do Supremo Tribunal Federal, Eros Roberto Grau, relator do julgamento da $\mathrm{ADPF} / 153$ em seu voto contrário à revisão da Lei de Anistia:

$\mathrm{O}$ arguente alega ser notória a controvérsia constitucional a propósito do âmbito de aplicação da "Lei de Anistia". Sustenta que "se trata de saber se houve ou não anistia dos agentes públicos responsáveis, entre outros crimes, pela prática de homicídio, desaparecimento forçado, abuso de autoridade, lesões corporais, estupro e atentado violento ao pudor contra opositores políticos ao regime militar" (ADPF/153, 2010) 
Na prática, a procedência da demanda traria consigo a possibilidade de, no âmbito nacional, reabrir investigações e processos por abusos cometidos durante os "anos de chumbo", punindo os envolvidos pelos crimes cometidos. Diante disso, segundo o já citado Ministro,

É necessário dizer, por fim, vigorosa e reiteradamente, que a decisão pela improcedência da presente ação não exclui o repúdio a todas as modalidades de tortura, de ontem e de hoje, civis e militares, policiais ou delinqüentes (ADPF 153, 2010).

Em âmbito internacional, a busca pela punição aos agentes criminosos de ditaduras militares tem ocorrido de forma incisiva. A Corte Interamericana de Direitos Humanos já proferiu cinco acórdãos contra diferentes países considerando inválidas suas leis de autoanistia. Nesta situação se encontra o Brasil, que, em 24 de novembro de 2010, teve julgado contra si demanda referente às atrocidades cometidas durante a Guerrilha do Araguaia, na qual cerca de 70 pessoas, entre membros do Partido Comunista do Brasil e camponeses da região, foram torturadas e assassinadas. Desses, vários corpos jamais foram localizados. Segundo o relatório da Comissão Interamericana.

Os peticionários entendem que a indenização não é uma reparação completa da violação e alegam que o Estado não pode com a indenização pretender ter reparado a totalidade da violação, pois ainda falta identificar e punir os responsáveis pela mesma. O Estado alega, por sua vez, que em virtude da Lei de Anistia não é possível investigar a responsabilidade individual e sancionar os agentes públicos envolvidos no caso. A Comissão considera no presente caso que deve considerar se a Lei de Anistia aprovada, no tocante aos fatos em que se enquadram os denunciados, estabelece um regime de impunidade, que impediria que os tribunais competentes julguem e estabeleçam uma condenação aos eventuais responsáveis das violações denunciadas (CIDH, Relatório $\mathrm{n}^{\mathrm{o}}$ 33/01, Caso no 11.552 , 2010) (Arantes, 2010a). 
Os argumentos defensivos não foram aceitos, ocasionando a condenação de forma unânime do Brasil pelo desaparecimento forçado e, portanto, pela violação dos direitos ao reconhecimento da personalidade jurídica, à vida, à integridade pessoal, à liberdade pessoal e à liberdade de pensamento. Entenderam os juízes da Corte que o Estado brasileiro descumpriu a obrigação de adequar seu direito interno à Convenção Americana sobre Direitos Humanos, incluindo neste item a controversa Lei de Anistia.

O Brasil restou condenado também a conduzir eficazmente as investigações penais dos fatos que ensejaram a demanda, determinando o paradeiro das vítimas desaparecidas, identificando e entregando os restos mortais a seus familiares, além de oferecer tratamento médico e psicológico/psiquiátrico às vítimas que o requeiram. Dentre as diversas condenações trazidas, o Estado ainda deverá realizar um ato público de reconhecimento de responsabilidade internacional a respeito dos fatos do caso Araguaia, tudo supervisionado pela Corte e sem a possibilidade de recurso.

De forma conclusiva, entenderam os juízes que compõem a Corte Interamericana de Direitos Humanos que as medidas adotadas pelo Brasil, como a Lei de Anistia e a política de indenizações e benefícios, não se constituíram em uma "reparação suficiente" das violações alegadas pelas vítimas.

Segundo consta no Relatório n⿳0 33/01, Caso n⿳0 11.552 da Comissão Interamericana de Direitos Humanos:

No presente caso, não seria possível à Comissão definir o que é uma reparação suficiente das violações, sem antes determinar a existência e a natureza das eventuais violações, o que só pode ser determinado na fase de mérito. Por estas razões, a Comissão entende desestimar a alegação do Estado de que devem se aplicar as hipóteses dos artigos 48(b) (e) (c) da Convenção. 
Os fatos alegados na petição, se comprovados, caracterizariam violações dos artigos I, XXV e XXVI da Declaração Americana, assim como dos artigos 1(1), 4, 8, 12, 13 e 25 da Convenção Americana. A Comissão considera que a exceção do artigo 47(b) não se aplica ao presente caso (CIDH, Relatório n⿳ํㅜ 33/01, Caso nº 11.552, 2010) (Arantes, 2010a).

A possibilidade de divergências entre os julgados externos e internos, à semelhança do ocorrido nos países latino-americanos vítimas de ditaduras militares, pressionou o Supremo Tribunal Federal a pacificar seu entendimento no sentido de proteção aos direitos humanos.

Frise-se de antemão que o STF, no dia 3 de dezembro de 2008, decidiu (historicamente) que os tratados internacionais de direitos humanos valem mais do que a lei e menos que a Constituição, estando no nível supralegal no país (cf. RE466.343/SP). Ainda que não tenha a Suprema Corte atribuído nível constitucional aos tratados de direitos humanos (por um voto faltante apenas), o certo é que trilhou o STF o caminho juridicamente correto (de respeito ao direito internacional dos direitos humanos, tal como vem sendo construído e seguido por todos os países civilizados) (Gomes; Mazzuoli, 2011, p. 51).

Este entendimento, no entanto, encontra-se em xeque. A recente decisão proferida pela Corte Interamericana de Direitos Humanos obrigou o país a revisar sua Lei de Anistia, decisão anteriormente negada pelo STF e que deverá trazer mudanças drásticas nos rumos políticos e jurídicos do Brasil.

\section{A ABERTURA POLÍTICA E A LEI DE ANISTIA (LEI № 6.683/79)}

Imediatamente após a edição do primeiro Ato Institucional, a oposição iniciou sua campanha pela anistia dos atingidos pelo golpe militar. Ignorados pela Junta Militar que governava o país naquele momento, foi 
reiterada posteriormente ao então presidente da República Castelo Branco que, igualmente, a desprezou. As tentativas, porém, se sucederam ao longo dos anos, como relembra Glenda Mezarobba.

Em seguida foi a vez do general Pery Constant Bevilacqua, ministro do Superior Tribunal Militar (STM), defender a adoção do expediente. Três anos mais tarde, reclamando "anistia geral, para que se dissipe a atmosfera de guerra civil que existe no país”. A Frente Ampla organizada por líderes da oposição como Carlos Lacerda, Juscelino Kubitchek e João Goulart, lançou um manifesto com o mesmo objetivo (2009, p. 157).

Somente em 1975 a oposição conseguiu, de modo ordenado, estabelecer a luta pela anistia ampla, geral e irrestrita aos presos políticos no Brasil. Influenciados pelo decreto-lei assinado por Getúlio Vargas, que em 1945 havia concedido a anistia aos presos e exilados do Estado Novo, alguns movimentos de oposição passaram a se destacar nas campanhas pela redemocratização. Dentre os mais relevantes, o Movimento Feminino pela Anistia e Liberdades Políticas (MPFA) e, em 1978, os Comitês Brasileiros pela Anistia (CBA), espalhados em vários Estados. O cidadão passou a externar sua oposição ao regime somente a partir de 1977, quando, com o apoio de artistas, sindicatos e do movimento estudantil (UNE), foi às ruas para protestar (Dossiê Ditadura, 2009, p. 23).

Os movimentos de oposição ao regime estavam fortalecidos e as lideranças sindicais, principalmente do Sindicato dos Metalúrgicos de São Bernardo do Campo e Diadema, demonstravam sua força por intermédio das greves.

Com a greve dos metalúrgicos de 1978, o movimento trabalhista surgiu como força de primeiro plano na cena política. Pelos padrões brasileiros, os metalúrgicos estavam entre os trabalhadores melhor pagos do país, em 1978. [...] Os metalúrgicos de São Bernardo do Campo e Diadema sabiam que ocupavam uma posição privilegiada no quadro produtivo brasileiro, e estavam perfeitamente conscientes de sua capacidade de "paralisar o sistema" (Alves, 1984, p. 247). 
No final da década de 70, o Brasil encontrava-se em delicada situação econômica. Comparativamente, afirma Eduardo Bueno, "se, durante o governo Médici, a economia ia bem e o povo mal, durante os seis longos anos do governo Figueiredo tanto a economia quanto o povo foram tremendamente mal”. A crise do petróleo, a inflação e a dívida externa prejudicavam a imagem dos militares, fortalecendo o discurso da oposição, que, destemida desde a revogação do Ato Institucional no 5 em 31 de dezembro de 1978, passou a deflagrar a campanha pelas “Diretas Já” (2010, p. 400).

Mais euforia seria trazida pelo "milagre econômico". De 1969 a 1973, de fato ocorreu um extraordinário crescimento econômico no país. O PIB cresceu na espantosa média anual de 11\% (chegando a 13\% em 1973). Houve uma febre de investimentos, grandes obras (muitas delas faraônicas e muito dinheiro vindo do exterior, com juros baixos). O ministro Delfim Netto foi o articulador do "milagre". Logo o processo de crescimento se revelaria mais terreno do que "milagroso". Com a crise do petróleo, iniciada em 1974, e a consequente retração do capitalismo internacional, o "milagre" mostrou sua face real: o que ocorreu no Brasil durante o governo Médici foi um brutal processo de concentração de renda e o crescimento desmedido da dívida externa e do fosso social que separava ricos de pobres. O país ia bem, e o povo, de mal a pior (Bueno, 2010, p. 393).

A morte do jornalista Vladimir Herzog, em 24 de outubro de 1975, acabou por insuflar a campanha pela anistia. Nascido na Iugoslávia (atual Croácia), era chefe do Departamento de Jornalismo da TV Cultura (SP) e editor de cultura da revista Visão. Intimado pelas forças de segurança que realizavam a "Operação Jacarta”, compareceu espontaneamente para o interrogatório. Na mesma tarde morreu nas instalações do Destacamento de Operações de Informações - Centro de Operações de Defesa Interna (DOI-Codi). A versão oficial foi de suicídio em sua cela, enforcando-se com sua própria gravata. Seu corpo foi enviado à viúva em caixão lacrado e sem maiores explicações (Chagas, 1985, p. 228). 
Herzog era um jornalista conhecido e estimado. O estado de São Paulo foi subitamente tomado de maciça indignação popular com sua morte. Assistida por advogados da Ordem dos Advogados do Brasil e da Comissão Arquidiocesana de Justiça e Paz, sua viúva, Clarice Herzog, contestou a versão de suicídio e entrou com ação contra o governo federal, responsabilizando-o pela morte do marido. O caso obteve $o$ apoio de jornalistas de todo o país. A imprensa promoveu aprofundada investigação paralela, demonstrando que na realidade Vladimir Herzog fora morto por tortura na sede do DOI-CODI do Segundo Exército. A Associação Brasileira de Imprensa reuniu assinaturas de 1.000 destacados jornalistas num abaixo-assinado pedindo investigação das atividades do DOI-Codi (Alves, 1984, p. 205).

As mortes ocorridas durante as sessões de tortura fortaleceram a oposição, que passou a contar com o apoio do Cardeal Paulo Evaristo Arns, tendo solicitado pessoalmente o apoio dos bispos presentes à Conferência Regional dos Bispos em Itaici, São Paulo. Além da Igreja Católica, a União Nacional dos Estudantes (UNE), que se reorganizava politicamente, aderiu à campanha, como relembra Maria Helena Moreira Alves:

Após a morte de Manoel Fiel Filho, o governo Geisel viu-se sob forte pressão para acabar com a repressão em São Paulo. Os chefes das forças de segurança de São Paulo - o comandante do Segundo Exército, Ednardo D’Ávila Mello, e o Coronel Erasmo Dias - integravam o setor linha-dura contrário à política de “distensão". Estimou-se que suas atividades em São Paulo redundavam no exercício de um poder paralelo que poderia ameaçar a autoridade do Executivo central e do próprio Estado de Segurança Nacional. O Presidente Geisel agiu com rapidez para recuperar o controle da situação. Dois dias depois da morte de Manoel Fiel Filho, ele afastou o General D’Ávila Mello, substituindo-o, no comando do Segundo Exército, pelo General Dilermando Gomes Monteiro. [...] Embora o General Dilermando Gomes Monteiro, considerado um "militar liberal", mantivesse a sua promessa de acabar com a tortura nas dependências do DOI-CODI de São Paulo, não pode evitar novos atos de repressão em São Paulo, desta vez contra estudantes universitários que tentavam reorganizar a extinta UNE (1984, p. 207). 
Neste cenário de conquistas da oposição política, o Movimento Feminino pela Anistia (MPFA), surgido em 1975, passou a expandir-se pelo país. Sob a liderança da advogada Therezinha Zerbine, esposa de um general cassado pelo regime, reuniu 16 mil assinaturas para o "Manifesto da Mulher Brasileira”, que reivindicava a anistia política. Em âmbito político-jurídico, o precursor de um projeto de anistia aos crimes cometidos na ditadura militar de 1964 foi o deputado Paulo Macarini (MDB-SC), que, em 1968, foi derrotado no Congresso, mas mostrou que a anistia já encontrava ecos na sociedade brasileira.

Além disso, no plano do poder instituído, em 1967, formara-se no Congresso Nacional a "Frente Ampla", que exigia a redemocratização, a revogação da legislação de controle e a realização de eleições livres e diretas. Em seu manifesto de lançamento, a Frente reclamava também "Anistia Geral, para que se dissipe a atmosfera de guerra civil que existe no país”. Pouco depois, em agosto de 1968, o deputado Paulo Macarini (MDB-SC) apresentava o primeiro projeto de anistia, que anistiaria todos os punidos em decorrência do envolvimento nas manifestações em razão da morte do estudante Edson Luís. Mesmo derrotado no Congresso, mostraria que a demanda da anistia já encontrava ecos na sociedade brasileira (Del Porto, 2009, p. 61).

Apesar da contribuição dada pelos movimentos já constituídos, em 14 de fevereiro de 1978, no Rio de Janeiro, foi fundado o Comitê Brasileiro pela Anistia (CBA), que teve por característica a capacidade de unificar os diferentes grupos de oposição, reunindo militantes de diferentes categorias na busca pela anistia. Esse comitê era composto por integrantes do MFPA, estudantes, advogados, artistas e membros da Igreja Católica, e estabeleceu uma articulação com as oposições sindicais e representantes de movimentos de bairros.

Com a revogação do AI-5, a campanha pela anistia passou a ter maior visibilidade. Os opositores puderam expressar seu desejo em rever familiares e amigos há anos exilados fora do país. 
Nas ruas e nos campos de futebol era possível ver cartazes e faixas defendendo a adoção do expediente. Carros também exibiam adesivos plásticos nos vidros, panfletos eram distribuídos nas esquinas e comícios buscavam sensibilizar a opinião pública a respeito do assunto. A orientação dos movimentos de anistia era de que a bandeira fosse estendida à prática dos sindicatos, das associações de bairro, das entidades profissionais e nos meios estudantis (Mezarobba, 2009, p. 160).

A fundação de comitês estaduais fortaleceu e divulgou o ideário de uma Anistia Ampla, Geral e Irrestrita, conforme relembra Maria Auxiliadora de Almeida Cunha Arantes:

Os Comitês Brasileiros pela Anistia (CBAs) surgem como uma organização independente, reunindo homens e mulheres dispostos a levar à frente um programa político mínimo e de ação que ia além do esquecimento e exigia a libertação imediata de todos os presos políticos; a volta de todos os exilados, banidos e cassados; a reintegração política, social e profissional dos funcionários públicos ou privados demitidos por motivos políticos em consequência dos efeitos dos Atos de Exceção; o fim radical e absoluto da tortura; a revogação da Lei de Segurança Nacional; o desmantelamento do aparato repressivo; o esclarecimento das mortes e dos desaparecimentos por motivação política; a denúncia sistemática da tortura e dos casos de mutilação; o julgamento e punição dos responsáveis (2009, p. 84).

Também no exterior foram criados comitês de anistia. Compostos por exilados políticos e estrangeiros contrários aos regimes ditatoriais, expuseram ao mundo a situação repressiva pela qual o Brasil estava passando. Pode-se ousar dizer, conforme palavras de Heloisa Amélia Grecco, "que o movimento chegou a assumir caráter de massa, ao menos na medida em que isso seria possível naquele momento” (2009, p. 200).

Os comitês de anistia foram brotando em quase todas as capitais da Europa. Aqui na Suécia não se restringiram a Estocolmo mas existem em Upsalla, Lund e Gotemburgo, todas cidades importantes. Em Paris, onde se fez uma noite pela anistia, mais de cinco mil pessoas apare- 
ceram para ver os filmes, as exposições. Inúmeras personalidades se comprometeram com a luta pela anistia no Brasil. A própria Amnesty Internacional passou a encarar a possibilidade de uma ofensiva no caso específico do Brasil. Saiu daqui o Thomas Hamamberg, saiu a representante de Londres e todos foram para aí, para dar uma olhada (Gabeira, 1980, p. 14).

Diante da forte pressão exercida pelos diferentes segmentos da sociedade civil, os parlamentares passaram a elaborar projetos de lei que tratavam do assunto. A Constituição (Emenda Constitucional no 1 ) outorgada em 1969, porém, antevendo os fatos, havia tornado privativo do presidente da República o ato de anistia, o que resultou nas seguidas derrotas dos projetos apresentados pelos deputados de oposição.

Em 22 de agosto de 1979, o projeto de anistia mais ampla, o MDB, foi derrotado por 209 votos contrários e 194 a favor. Em seguida, ocorreu a votação da emenda Djalma Marinho, cuja redação era mais clara e possibilitava uma anistia mais abrangente, mas foi derrotada por 206 votos contrários contra 201 a favor. Dessa forma, apesar da pequena margem de votos entre as propostas, o Congresso aprovou o projeto de anistia proposto pelo presidente, general João Figueiredo (Dossiê Ditadura, 2009, p. 23).

Nesse clima de cobranças democráticas, o presidente da República João Figueiredo, eleito de forma indireta em 15 de outubro de 1978 e empossado em 15 de março de 1979, encaminhou ao Congresso Nacional em junho de 1979 o projeto da Lei de Anistia. Severamente criticado por seu caráter de autoanistia, teve a clara intenção de garantir a inimputabilidade daqueles que perpetraram torturas, assassinatos e desaparecimentos forçados a serviço da ditadura militar, além de anistiar os exilados políticos e demais opositores ao regime.

A Lei $\mathrm{n}^{\circ} 6.683$, aprovada no Congresso a 22 de agosto e promulgada a 28 de agosto de 1979 - Lei de Anistia parcial (a anistia de agosto) - é a representação da anistia-amnésia, logo, da estratégia do esquecimento 
e da produção do silenciamento. Ela reflete exemplarmente a lógica interna de sua matriz - a Doutrina de Segurança Nacional - sobretudo através de três dos seus dispositivos, expressos nos dois primeiros parágrafos do art. $1^{\circ}$ e no art. $6^{\circ}$, respectivamente, todos eles voltados para o ocultamento da verdade e a interdição da memória: a pretensa e mal chamada reciprocidade atribuída à inclusão dos crimes conexos; a exclusão dos guerrilheiros, aqueles que praticaram crime de sangue, no jargão dos militares; e a declaração de ausência a ser concedida aos familiares dos desaparecidos políticos (Greco, 2009, p. 211).

Aos opositores exilados a Lei de Anistia representou a conquista do direito de retornar ao Brasil; aos cassados, o retorno aos seus empregos. Já aos presos políticos não envolvidos em crimes comuns, também chamados de “crimes de sangue”, a concessão do direito à liberdade.

Os presos políticos condenados pelos chamados "crime de sangue"considerados na lei crimes de terrorismo, assalto, sequestro e atentado pessoal - não foram beneficiados pela anistia, permaneceram nos cárceres e somente foram libertados em função da reformulação da Lei de Segurança Nacional ocorrida em 1978, que atenuou suas penas. Eles foram soltos em liberdade condicional, vivendo nessa condição durante muitos anos após a anistia (Dossiê Ditadura, 2009, p. 24).

$\mathrm{O}$ período imediatamente posterior à entrada em vigor da Lei $\mathrm{n}^{0}$ $6.683 / 79$ foi marcado pelo retorno de artistas e políticos que haviam sido forçados a abandonar o país, dentre os quais Leonel Brizola, Caetano Veloso e Gilberto Gil. Professores universitários e cientistas que não fixaram residência permanente no exterior aos poucos retornaram ao Brasil, e os que deixaram de retornar contabilizaram um prejuízo sem precedentes à educação e ao desenvolvimento do país.

Premeditadamente os nomes dos anistiados eram divulgados no Diário Oficial da União e algumas listas foram reproduzidas em jornais de grande circulação. A justificativa da publicização era de que a anistia havia 
sido concedida individualmente, porém, o real objetivo era o de manter a ordem e também o controle sobre os autores de crimes comuns que, segundo os militares, não deviam ser anistiados.

A principal controvérsia gerada pela Lei de Anistia, no entanto, se deu com a não individualização e responsabilização dos mandantes ou responsáveis pelas torturas, assassinatos ou desaparecimentos forçados. Esses agentes do governo sequer foram julgados ou indiciados em processos criminais. Eles serviram-se da bilateralidade da lei para garantir o próprio salvo-conduto.

Visando a influenciar a elaboração de uma lei sem normas ambíguas ou desfavoráveis aos já combalidos opositores, mas também aventando a possibilidade de punição aos criminosos a serviço do sistema, os movimentos organizados fizeram suas reivindicações e sugestões. Conforme ressalta Larissa Brisola Brito Prado.

Em razão do alcance que essa medida teria, foram muitas as reivindicações dentro da sociedade civil, especialmente por parte do Movimento Feminino pela Anistia - capitaneado por Terezinha Zerbine -, da OAB (Ordem dos Advogados do Brasil), da ABI (Associação Brasileira de Imprensa), da Igreja, dos sindicatos - dos metalúrgicos, dos bancários, dos médicos, entre outros - e dos estudantes, (2009, p. 174).

Relembra Glenda Mezarobba que “durante a tramitação do projeto de anistia do governo, houve quem, como o Deputado Octacílio Queiroz (MDB-PB), propusesse emendas prevendo o pagamento de pensões mensais a todas as mães, viúvas, menores órfãos, esposa e filhos de pessoas desaparecidas [...]” (2009, p. 162).

A pressão mais contundente, porém, por parte da oposição que visava à inclusão de artigos que possibilitassem a punição dos militares, não demoveu o presidente da República João Figueiredo. Para preservar seus aliados que, a serviço do sistema, cometeram abusos no exercício de suas funções, fatos sempre rechaçados pelo presidente, e também preser- 
var a imagem das Forças Armadas como instituição, não houve a inclusão na Lei de Anistia de normas que imputassem crimes aos atos que violaram os direitos e garantias fundamentais durante o regime.

A redação da Lei de Anistia visava tão somente a evitar a possibilidade de interpretações desfavoráveis aos militares. $\mathrm{O}$ artigo $1^{0}$ e seus dois primeiros parágrafos expressam claramente os fundamentos e objetivos de seu sancionamento.

Art. $1^{\circ}$ É concedida anistia a todos quantos, no período compreendido entre 02 de setembro de 1961 e 15 de agosto de 1979, cometeram crimes políticos ou conexo com estes, crimes eleitorais, aos que tiveram seus direitos políticos suspensos e aos servidores da Administração Direta e Indireta, de fundações vinculadas ao poder público, aos Servidores dos Poderes Legislativo e Judiciário, aos Militares e aos dirigentes e representantes sindicais, punidos com fundamento em Atos Institucionais e Complementares.

$\S 1^{\circ}$ Consideram-se conexos, para efeito deste artigo, os crimes de qualquer natureza relacionados com crimes políticos ou praticados por motivação política.

$\S 2^{o}$ Excetuam-se dos benefícios da anistia os que foram condenados pela prática de crimes de terrorismo, assalto, sequiestro e atentado pessoal (Lei $\left.\mathrm{n}^{\mathrm{o}} 6.683 / 79\right)$.

A redação do artigo $1^{\circ}$ da Lei de Anistia evidenciou a intenção dos militares de desvincular os atos de tortura cometidos por seus agentes de qualquer possibilidade de punição futura. A delimitação de um prazo iniciado exatamente no dia 2 de setembro de 1961 fez retroagir o direito à anistia aos militares responsáveis pela instituição do parlamentarismo em detrimento ao presidencialismo legalmente constituído, fato que possibilitou a posse de João Goulart nessa mesma data. Manobra política somente possível mediante o desrespeito à Constituição Federal de 1946, o que poderia ser interpretado como crime político cometido pelos militares. 
A inserção da expressão “crimes conexos”, termo jurídico que conecta um delito a outro, seja na sua realização ou ocultação, significou a anistia ampla, geral e irrestrita aos agentes do governo. Militares ou civis que, no exercício de suas funções, cometeram crimes comuns, como torturas, estupros, assassinatos e ocultação de cadáver.

O objetivo do retorno ao tão almejado regime democrático, que permitiria a volta de familiares exilados, fez com que a oposição concordasse com a redação apresentada, formalizando na lei o interesse de ambas as partes.

A anistia representou o silêncio e o esquecimento sobre os envolvidos nas ações repressivas após o golpe de 1964. Na prática, os torturadores foram anistiados graças à interpretação de que a abertura política poderia retroceder caso as oposições reivindicassem justiça. O termo "revanchismo" tem sido utilizado para denominar de forma pejorativa a posição daqueles que insistem em investigar os casos dos mortos e desaparecidos pela repressão política e exigem o julgamento dos responsáveis por tais crimes. A anistia, porém, segundo o Direito Internacional de Direitos Humanos, não pode ser um impedimento ao direito à verdade, que pressupõe a ampla investigação sobre a atuação dos órgãos de repressão durante a ditadura. A investigação é a medida fundamental para aprofundar e fortalecer a democracia, e o combate à impunidade é necessário para coibir a prática de tortura no país (Dossiê Ditadura, 2009, p. 24).

O significado da palavra anistia, expresso no Dicionário Jurídico, traduz de forma categórica o objetivo do governo militar e da oposição com a edição da Lei de Anistia.

Anistia. Ato de soberania de competência do Congresso Nacional pelo qual o poder público declara extinta a culpa, por motivo de utilidade social, de todos quantos, até certo dia, perpetraram determinados delitos, em geral políticos, pelo ato de fazerem cessar as diligências persecutórias, e se tornam nulas e de nenhum efeito as condenações; pode ser absoluta, condicional, geral, plena (De Paulo, 2004, p. 39). 
Embora a Lei de Anistia tenha sido promulgada em 28 de agosto de 1979, o retorno dos exilados políticos não ocorreu de forma imediata. " $\mathrm{Na}$ década de 1980, a anistia conquistada ainda não havia beneficiado muitos dos exilados, sindicalistas, banidos, marinheiros e trabalhadores de uma maneira geral” (Dossiê Ditadura, 2009, p. 24). Os benefícios da anistia não foram sentidos no primeiro momento, porque ainda se estava sob o domínio militar. Mesmo que as intenções democráticas partissem do próprio governo, sua natureza era ditatorial, prejudicando a efetividade da lei.

Tempos depois da promulgação da Lei de Anistia Marcelo Cerqueira sustentou no tribunal a primeira ação declaratória no cível por perdas e danos, para efeito de indenização, a favor de Inês Etienne Romeu, a Alda, da Vanguarda Popular Revolucionária (VPR). A história de Inês foi escrita e amplamente divulgada por sua irmã, a jornalista Lúcia Etienne Romeu, por meio das reportagens "A casa dos horrores" e "A torturada fala com o médico da tortura”, publicadas na Revisto Isto É. Inês foi mantida em cárcere privado de maio a agosto de 1971 em uma casa situada na serra de Petrópolis, no Estado do Rio de Janeiro, que servia de centro clandestino de tortura. [...] Inês foi julgada por sequestro e condenada à prisão perpétua. Cumpriu oito anos e três meses de sentença no Presídio Talavera Bruce, situado na Zona Norte do Rio. Foi beneficiada com a Lei de Anistia, de 1979, mas só foi libertada no ano de 1981 (Pessoa; Melo, 2010, p. 172).

Buscando a reparação das injustiças, a Constituição Federal de 1988, no artigo $8^{\circ}$ das Disposições Transitórias, estabeleceu o direito ao reconhecimento dos anos de prisão ou de clandestinidade como tempo de serviço. As controvérsias da Lei de Anistia, no entanto, se mantiveram mesmo após o retorno do país ao Estado Democrático de Direito. A política de reparações surgida somente por meio da Medida Provisória 2.151 de 21 de maio de 2001, editada pelo presidente da República Fernando Henrique Cardoso, deu início ao pagamento de indenizações pecuniárias às vítimas da ditadura militar, incluídos os militares anistiados pela Lei $6.683 / 79$. 


\section{A COMISSÃO DA VERDADE E A LEI DE ACESSO À INFORMAÇÃO}

Concomitantemente à sanção presidencial que criou a Comissão da Verdade (Lei $\mathrm{n}^{\mathrm{o}}$ 12.528/2011), a presidente da República Dilma Roussef sancionou a lei que permite aos cidadãos o acesso às informações públicas (Lei $\mathrm{n}^{0} 12.527 / 2011$ ). A criação de ambas as leis já havia sido imposta ao Brasil por meio da sentença proferida pela Corte Interamericana de Direitos Humanos no julgamento do caso da Guerrilha do Araguaia. Apesar de a condenação se referir aos envolvidos na Guerrilha, projetos de lei visando à criação de uma Comissão Nacional da Verdade e de acesso a informações públicas já tramitavam no Congresso Nacional.

Apesar da iniciativa brasileira, os juízes da Corte Interamericana de Direitos Humanos teceram severas críticas aos moldes adotados pelo legislador nacional, expressando na sentença a preocupação com a forma adotada para sua constituição.

Quanto ao projeto de lei que atualmente se encontra no Congresso, expressaram sua preocupação, entre outros aspectos, por que os sete membros da Comissão Nacional da Verdade seriam escolhidos discricionariamente pelo Presidente da República, sem consulta pública e, portanto, sem garantias de independência e, ademais, que se permitiria a participação de militares como membros, o que afeta gravemente sua independência e credibilidade (CIDH, 2010, p. 106) (Arantes, 2010a).

As críticas quanto à forma de composição da Comissão da Verdade não modificaram sua configuração, centralizando na presidente da República este poder. Esta condição tem explicitado o temor nos meios militares, principalmente entre aposentados e agentes públicos que faziam parte do governo entre os anos de 1964 e 1985, de serem investigados, processados e julgados por vítimas diretas ou indiretas de seus crimes. 
Segundo palavras da própria presidente Dilma Roussef, ex-guerrilheira e vítima das violações de direitos por parte dos militares, estas leis têm o condão de evitar que "nenhum ato nem documento que atente aos direitos humanos possa ficar sob sigilo, o sigilo não oferecerá nunca mais guarida ao desrespeito aos direitos humanos no Brasil” (Alcântara, 2011).

Em defesa dos militares, a Lei de Anistia afasta qualquer possibilidade de punição atual para eventos do período investigado, porém, apesar da improcedência da ADPF 153, a Corte Interamericana de Direitos Humanos destinou espaço na sentença para, de forma incisiva, questionar sua manutenção.

135. Em virtude dessa lei, até esta data, o Estado não investigou, processou ou sancionou penalmente os responsáveis pelas violações de direitos humanos cometidas durante o regime militar, inclusive as do presente caso 173. Isso se deve a que "a interpretação [da Lei de Anistia] absolve automaticamente todas as violações de direitos humanos que tenham sido perpetradas por agentes da repressão política" 174 (CIDH, 2010, p. 50) (Arantes, 2010a).

Assim sendo, a coexistência de uma Comissão da Verdade com a lei que concede a anistia aos investigados, representa a falta de convicção do governo brasileiro quanto ao melhor caminho a ser seguido. Significa a imposição da decisão estrangeira proferida pela Corte Interamericana de Direitos Humanos que, ao aplicar decisões análogas em outros países, constatou o progresso democrático pela prestação de contas com o passado e suas vítimas.

A Comissão da Verdade poderá pedir à Justiça acesso a documentos privados, investigar violações aos direitos humanos, com exceção dos crimes políticos, de motivação política e eleitorais abrangidos pela Lei da Anistia, "promover a reconstrução da história dos casos de violação de direitos humanos" e disponibilizar meios e recursos necessários para a localização e identificação dos restos mortais de desaparecidos políticos (Alcântara, 2011). 
As pressões externas sofridas pelo Brasil no sentido de revisar a Lei de Anistia tem ameaçado a soberania do Supremo Tribunal Federal. Este, ao julgar improcedente a revisão da referida lei, refletiu a importância dada pela maioria da sociedade brasileira ao caso. Sua revisão, porém, se mostra inevitável, aproximando os militares ainda vivos de condenações por seus crimes cometidos durante o regime militar.

De forma abrangente, entretanto, a Comissão da Verdade está sendo criada para a investigação, em apenas dois anos, das violações aos direitos humanos ocorridos entre 1946 e 1988. A comissão não terá poder de julgar; apenas de emitir relatórios sobre as investigações, sendo destituída ao final do segundo ano.

As condições impostas para criação da Comissão da Verdade serão facilmente subjugadas a partir da revisão da Lei de Anistia, expondo militares às condenações já aplicadas em países vizinhos, punições que não representam o interesse nacional, mas que esperam das autoridades a solução de problemas imediatos que reflitam na qualidade de suas vidas.

\section{CONCLUSÃO}

A condenação sofrida pelo Estado brasileiro perante a Corte Interamericana de Direitos Humanos já começou a repercutir nos meios políticos do país. O fato de muitos agentes militares da época da ditadura ainda fazerem parte do poder dificulta a efetivação plena do julgado. Recentemente o deputado federal e militar da reserva, Jair Bolsonaro (PP-RJ), criticou veementemente a forma adotada pelo Legislativo brasileiro para a instituição da Comissão da Verdade, um dos itens que compõe a decisão imposta pela Corte.

Afirmando falar em nome dos oficiais generais do Exército, Bolsonaro condenou a iniciativa do Palácio do Planalto de aprovar o grupo de trabalho que terá por função examinar as violações de direitos humanos 
durante os anos de 1946 e 1988. Tentando preservar a imagem dos militares aposentados e falecidos que prestaram serviços entre 1964 e 1985, questiona a intenção do governo de "efetivar o direito à memória e à verdade histórica e promover a reconciliação nacional” mediante esses meios.

A inquestionável evolução brasileira ocorrida após 1985 selou o fim de uma era, culminando na promulgação da Constituição Federal de 1988 e seu exaustivo rol de direitos e garantias fundamentais. A busca pela efetividade dessas normas reflete a consolidação da democracia no Brasil, não parecendo ser determinante nesse processo a ocorrência de punições àqueles cidadãos brasileiros que, decorridos quatro décadas de seus crimes, afirmarão terem agido em nome da pátria.

Independentemente das possíveis consequências, a obrigação do Estado brasileiro de adequar seu direito interno à Convenção Americana de Direitos Humanos deverá ocorrer de forma pública e livre de questões políticas, prenunciando uma nova revolução nos meios políticos do país, cassando-se direitos adquiridos pela Lei de Anistia.

O respeito às vítimas daquele período histórico se demonstra por intermédio da indenização pecuniária às vítimas e seus familiares, forma que deve ser aperfeiçoada e encerrada quando do seu alcance pleno. As condenações penais no Brasil jamais tiveram a capacidade de ressocializar criminosos, o que se contrapõe ao objetivo das medidas que serão adotadas após longos anos de consolidação democrática, expondo os agentes ainda vivos da ditadura ao retrocesso da Lei de Talião, "olho por olho, dente por dente”.

\section{REFERÊNCIAS}

ALCÂNTARA, Diogo. Dilma sanciona hoje lei que cria Comissão da Verdade. Disponível em: $<\mathrm{http}: / /$ www.averdadesufocada.com/index.php?option=com_ content\&task=view\&id=6176>. Acesso em: 20 nov. 2011. 
ALVES, Maria Helena Moreira. Estado e oposição no Brasil (1964-1984). 2. ed. Petrópolis, RJ: Vozes, 1984.

ARANTES, Maria Auxiliadora de Almeida Cunha. O Comitê Brasileiro pela Anistia de São Paulo (CBA-SP): memórias e fragmentos. In: SILVA, Haike R. Kleber (Org.). A luta pela anistia. São Paulo: Editora UNESP; Arquivo Público do Estado de São Paulo: Imprensa Oficial do Estado de São Paulo, 2009.

. Corte Interamericana de Direitos Humanos. Relatório $n^{0} 33 / 01$, processo $n^{\circ}$ 11.552, Caso Gomes Lund e Outros vs. Brasil. Presidente Diego García-Sayán. Costa Rica, 24 de novembro de 2010a.

. Corte Interamericana de Direitos Humanos. Notificação da sentença, processo $n^{\circ}$ 11.552, Caso Gomes Lund e Outros vs. Brasil. Disponível em: <www. corteidh.or.cr>. Acesso em: 28 maio 2011.

. Lei 6.683, de 28 de agosto de 1979. Dispõe sobre a anistia e dá outras providências. Diário Oficial da União, Brasília, 1979.

Supremo Tribunal Federal. Arguição de Descumprimento de Preceito Fundamental $n^{\circ}$ 153. Conselho Federal da Ordem dos Advogados do Brasil e Congresso Nacional. Relator Ministro Eros Grau. Brasília, 29 de abril de 2010b.

BUENO, Eduardo. Brasil: uma história: cinco séculos de um país em construção. São Paulo: Leya, 2010.

COMPARATO, Fábio Konder. A afirmação histórica dos direitos humanos. 4. ed. São Paulo: Saraiva, 2005.

CHAGAS, Carlos. A guerra das estrelas (1964/1984): os bastidores das sucessões presidenciais. São Paulo: L\&PM, 1985.

DE PAULO, Antonio. Dicionário jurídico. 2. ed. Rio de Janeiro: DP\&A, 2004.

DEL PORTO, Fabíola. A luta pela anistia no regime militar brasileiro e a construção dos direitos de cidadania. In: SILVA, Haike R. Kleber da. et al. A luta pela anistia. São Paulo: Editora UNESP; Arquivo Público do Estado de São Paulo: Imprensa Oficial do Estado de São Paulo, 2009. 
DOSSIÊ DITADURA: mortos e desaparecidos políticos no Brasil (1964-1985). Comissão de Familiares de Mortos e Desaparecidos Políticos, IEVE - Instituto de Estudos sobre a Violência do Estado; organização Criméia Schmidt. 2. ed. São Paulo: Imprensa Oficial do Estado de São Paulo, 2009, 772 p.

GABEIRA, Fernando. Carta sobre a anistia; a entrevista do Pasquim; conversação sobre 1968. 3. ed. Rio de Janeiro: Codecri, 1980.

GRECO, Heloisa Amélia. Memória vs. Esquecimento, Instituinte vs. Instituído: a luta pela anistia ampla. In: SILVA, Haike R. Kleber da. et al. A luta pela anistia. São Paulo: Editora UNESP; Arquivo Público do Estado de São Paulo: Imprensa Oficial do Estado de São Paulo, 2009.

GOMES, Luiz Flávio Gomes; MAZZUOLI, Valério de Oliveira. Crimes contra a humanidade e a jurisprudência do Sistema Interamericano de Direitos Humanos. In: . Crimes da ditadura militar: uma análise à luz da jurisprudência atual da Corte Interamericana de direitos humanos: Argentina, Brasil, Chile, Uruguai. São Paulo: Editora Revista dos Tribunais, 2011.

MEZAROBBA, Glenda. In: SILVA, Haike R. Kleber da., et al. A luta pela anistia. São Paulo: Editora Unesp: Arquivo Público do Estado de São Paulo: Imprensa Oficial do Estado de São Paulo, 2009.

PESSOA, Gláucia; MELO, Mariana. Marcelo Cerqueira: da advocacia política na ditadura militar à luta pela anistia. In: MUNTEAL, Oswaldo (Org.). Os Advogados e a ditadura de 1964: a defesa dos perseguidos políticos no Brasil. Petrópolis/RJ: Vozes, 2010.

PRADO, Larissa Brisola Brito. A anistia de 1979: uma análise sobre seus reflexos jurídicos, políticos e históricos. In: SILVA, Haike R. Kleber da. et al. A luta pela anistia. São Paulo: Editora Unesp: Arquivo Público do Estado de São Paulo; Imprensa Oficial do Estado de São Paulo, 2009.

Recebido em: $11 / 3 / 2013$

Revisado em: 8/4/2013

Aceito em: $11 / 4 / 2013$ 